\title{
Editorial
}

Int Neurourol J 2011;15:1-1

doi: 10.5213/inj.2011.15.1.1

pISSN 2093-4777 • eISSN 2093-6931

\section{Future Challenges in Nocturia: Relevance to Voiding Clock?}

\author{
Tack Lee \\ Editor-in-Chief \\ Department of Urology, Inha University Hospital, Inha University School of Medicine, Incheon, Korea \\ E-mail: 1t11@inha.ac.kr
}

Sleep is a naturally stereotypical behavioral state, characterized by reduced or absent consciousness and inactivity of all voluntary muscles. However, sleeping is not just an inactive state, but an essential activity for survival, such as for the repair and renewing of our bodies. The timing of the sleep cycle is controlled by a complex interaction between the circadian clock and a separate sleep-wake homeostatic process. This complex interaction is also affected by the aging process [1].

Even though the precise functions and mechanisms of sleep are only partially understood, recent evidence suggests that the primary mammalian circadian timing system, which is located in the suprachiasmatic nucleus (SCN) of the hypothalamus, resets itself every day in response to light signals. The SCN receives information from the eye and transfers it to the pineal gland, the endocrine gland that secrets melatonin, the "hormone of darkness". Recent studies have found that melatonin has beneficial effects for the treatment of certain sleep disorders. Besides the SCN "master clock", independent circadian clocks are also found in many organs, such as the esophagus, lung, liver, pancreas, spleen, thymus, skin, and kidney, which constitute the socalled peripheral oscillators $[2,3]$. The presence of a bladder clock and influence by a kidney clock remain to be elucidated.

Nocturia is a common storage symptom with a significantly negative impact on health-related quality of life in aging people [4]. Because the average age of people in developed countries is increasing, it is expected that nocturia will become more common in the future, because the prevalence of nocturia increases with age. Although substantial efforts have been made to provide insights into the etiology of the disease and corresponding remedial actions, many unanswered questions remain about the bladder in terms of sleep.

The article by Cho et al. [5] in this issue of the journal will be recognized as a valuable landmark that lays the foundation for future research to shed some light on the circadian control of voiding function and dysfunction via the molecular clockwork. Through the International Neurourology Journal, we also hope to foster and reinforce the dialogue between basic researchers and health care providers.

\section{REFERENCES}

1. Berger RJ. Bioenergetic functions of sleep and activity rhythms and their possible relevance to aging. Fed Proc 1975;34:97-102.

2. Schibler U, Ripperger J, Brown SA. Peripheral circadian oscillators in mammals: time and food. J Biol Rhythms 2003;18:250-60.

3. Sly DJ, Colvill L, McKinley MJ, Oldfield BJ. Identification of neural projections from the forebrain to the kidney, using the virus pseudorabies. J Auton Nerv Syst 1999;77:73-82.

4. Tikkinen KA, Johnson TM 2nd, Tammela TL, Sintonen H, Haukka J, Huhtala $\mathrm{H}$, et al. Nocturia frequency, bother, and quality of life: how often is too often? A population-based study in Finland. Eur Urol 2010;57:488-96.

5. Cho SH, Han DH, Kim DH. Circardian rhythms in voiding function and dysfunction. Int Neurourol J 2011;15:2-3.

This is an Open Access article distributed under the terms of the Creative Commons Attribution Non-Commercial License (http://creativecommons.org/licenses/by-nc/3.0/) which permits unrestricted non-commercial use, distribution, and reproduction in any medium, provided the original work is properly cited. 